\title{
Proceeding Paper \\ Productivity Enhancement of Solar Water Desalination Unit Using a Solar Electric Water Heater ${ }^{\dagger}$
}

\author{
Kamran Mahboob ${ }^{1, *(\mathbb{D}}$, Qasim Awais ${ }^{2}$, Muhammad Yahya ${ }^{1}$, Muhammad Mehtab ${ }^{1}$ and Awais Khan ${ }^{1}$ \\ 1 Department of Mechanical Engineering, University of Engineering and Technology, Lahore 54890, Pakistan; \\ muhammad_yahya15@yahoo.com (M.Y.); muhammadmehtab08@gmail.com (M.M.); \\ awais211@uet.edu.pk (A.K.) \\ 2 Electrical Engineering Department, GIFT University, Gujranwala 52250, Pakistan; qasim.awais@yahoo.com \\ * Correspondence: mahboobccet@gmail.com \\ + Presented at the 1st International Conference on Energy, Power and Environment, Gujrat, Pakistan, \\ 11-12 November 2021.
}

check for

updates

Citation: Mahboob, K.; Awais, Q.;

Yahya, M.; Mehtab, M.; Khan, A.

Productivity Enhancement of Solar

Water Desalination Unit Using a

Solar Electric Water Heater. Eng. Proc.

2021, 12, 53. https://doi.org/

10.3390/engproc2021012053

Academic Editor: Shahid Iqbal

Published: 8 January 2022

Publisher's Note: MDPI stays neutral with regard to jurisdictional claims in published maps and institutional affiliations.

Copyright: (C) 2022 by the authors. Licensee MDPI, Basel, Switzerland. This article is an open access article distributed under the terms and conditions of the Creative Commons Attribution (CC BY) license (https:// creativecommons.org/licenses/by/ $4.0 /)$.

\begin{abstract}
The biggest problem faced by the world these days is pure drinkable water, and in a few years pure drinkable water will not be easily available, as it is becoming brackish and saline due to pollution. By using solar energy, a solar still can produce pure water which can be used for drinking, cooking, and also for industrial purposes. In this research, a solar still based on clean technology using solar energy to drive the system is used. It can be operated easily and with an approximately negligible maintenance cost. A pyramid solar water desalination unit with modification of the solar electric water heater (used to increase water temperature) is developed to increase the water yield per day. A theoretical model of the solar still unit with and without an electric water heater is developed and performance is compared. Based on this theoretical design, fabrication is carried out and experiments are performed to predict the overall output. It is observed that the output distilled water has a TDS (total dissolved salts) value much lower than the TDS of groundwater. Additionally, the average output of a solar water desalination unit with an electric water heater is found to be enhanced compared with the unit without an electric water heater.
\end{abstract}

Keywords: solar desalination; solar water heater; environment; design; TDS

\section{Introduction}

Good quality of drinkable water is a necessity for life. There are only a few available sources of water, such as lakes, rivers, and underground water. Mostly underground water is used for drinking. Underground water commonly has a high amount of different dissolved carbonates and salts which are not good for human health. Because of this, it cannot be directly used for drinking. Thus, there is a need to extract these carbonates and salts from water [1,2]. To produce freshwater that can be used for drinking purposes on a broader scale requires a high amount of energy. There are many purification methods of water, such as reverse osmosis, humidification, and dehumidification, electrodialysis, etc. [3,4]. For the purification of water, the simplest technology used is water desalination by solar energy. This system may use a single, double, or pyramid slope solar still [5]. The increase in energy utilization and its harmful results on the environment has produced interest in this simple technology [6,7]. Solar energy is available on Earth free of cost, and is also available easily, and reduces the cost of transportation. This energy can be utilized as thermal energy and has no pollution effect [8]. By using solar energy, a solar still can easily produce pure water which can be used for drinking, cooking, and also at an industrial scale. This is a very simple technology that uses solar energy and drives the system. It can be operated easily and approximately at a negligible maintenance cost [9]. 


\section{Basic Principle}

The purification of water through distillation is now considered a modern technique. Here, solar radiation is used to purify water and make it drinkable. By using solar energy water heads on the glass, impurities remain down in the basin and water condenses on the glass class cover. Glass has a low temperature as compared with water in the basin, and due to this temperature difference, the vapor condenses and move down to be collected through channels and an output pipe. This is the basic principle of the solar still, of any type and design.

\section{Objectives of the Study}

An experimental investigation to evaluate the performance of any mechanical instrument or device requires a lot of finance, time, and effort to accomplish the work and try to find the desired results. However, engineering has created many new methods to evaluate the performance of devices, as compared with the experimental investigation only. Hence, the objectives of the present work are:

To develop a theoretical model of a solar still;

To analytically model a solar desalination unit;

To conduct an economic analysis of the solar water desalination unit;

To fabricate the solar still of 30 lit. (approx) and perform experiments;

To perform parametric analysis of the solar still.

\section{Modification in Solar Still}

With time, solar still has been modified in new shapes with different radiationabsorbing materials and techniques to increase its output and efficiency, such as doubleslope, cone, pyramid, and double-basin solar stills, and many others have studied and compared their productivity [10-12]. The main considerations in a solar still are solar intensity, solar hours, and type of still. The productivity of any solar still depends upon the previous modifications made in solar stills such as using sun trackers, reflecting mirrors, and a stepwise basin to gain as much radiation in a day as possible. These modifications increased the productivity of the solar still but further modifications can be made to make the solar still more efficient with a higher output of distilled water [13]. The design of single-basin pyramid solar still is used, and modification involved the design of glass as shown in Figure 1 and, most importantly, the use of an electric water heater operated using a solar panel as shown in Figure 2. Firstly, one has to review and analyze past solar stills, their performance, results, and drawbacks. This provides an easy way to evaluate modified design improvement with traditional solar desalination systems.

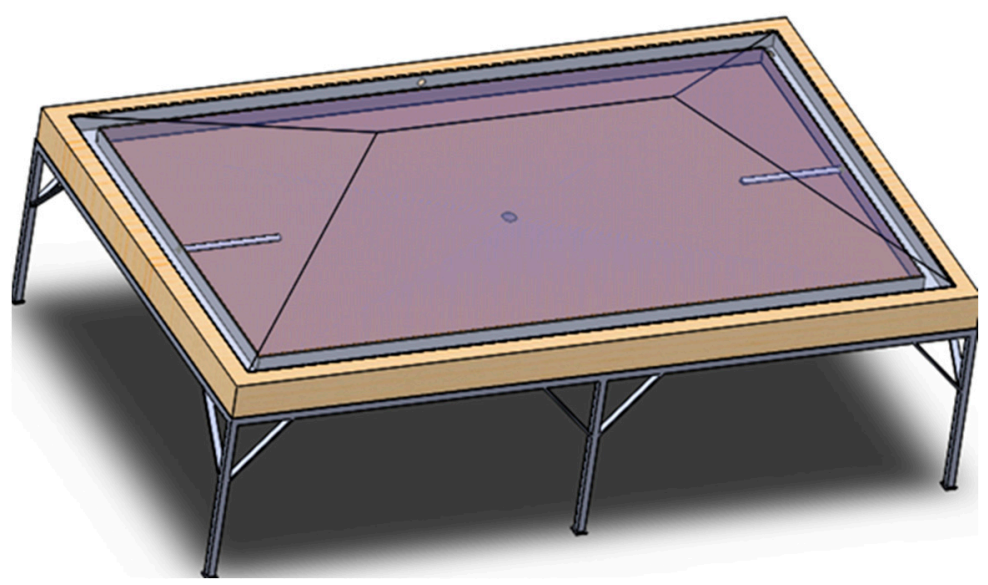

Figure 1. CAD model of pyramid solar water desalination unit. 

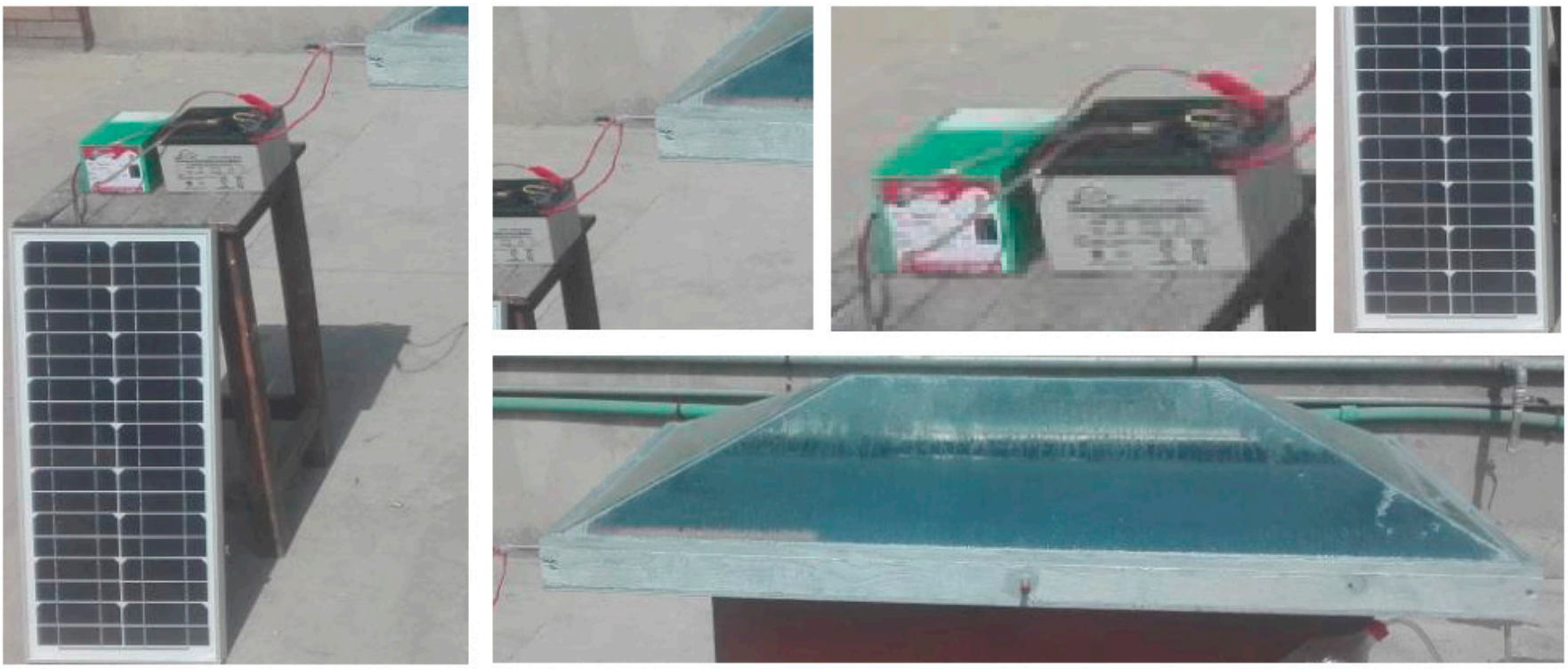

Figure 2. Physical model of pyramid solar water desalination unit with EWH.

\section{Scope of Work}

A study of previous work on solar water desalination units and a literature review was performed so that the development of a theoretical model was possible. Different tasks were executed as follows:

1. The model (based on heat transfer and thermodynamic principles) desalination unit as shown in Figure 3 was analyzed to install the electric water heater and PV panels as shown in Figure 2, and to find the effect of glass cover design, water basin, depth of water and insulation, etc. on the performance of the solar still and the effect of other factors such as absorptivity and transmittance.

2. The performance of the solar still was calculated by the theoretical modeling of a solar still and by energy balance equations. Using these equations, one can easily calculate the output of a solar still.

3. Through the performance and efficiency of a solar still, important characteristics and the effect of modifications of the solar still were studied that are helpful in further improvement.

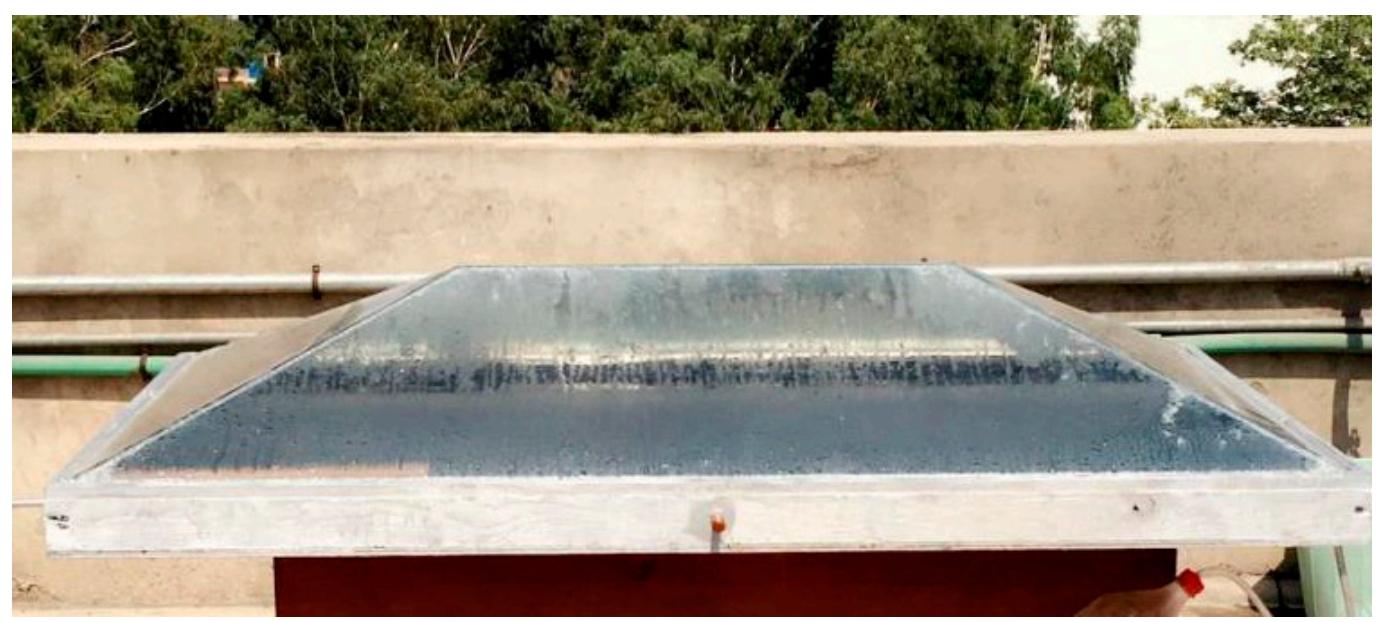

Figure 3. Physical model of pyramid solar water desalination unit without EWH. 


\section{Discussion}

The above experiments show that:

- Using black paint, the productivity of distillate can be increased.

- Modification of the glass cover leads to an increment in productivity.

- The use of an electric water heater increases the output and efficiency of the solar still.

\section{Conclusions}

The performance of a solar still with a DC electric water heater is predicted by its mathematical design and using standard parameters. The structural analysis of the model shows that our model will work smoothly and reliably. Additionally, the thermal analysis shows that the use of a water heater increases the temperature of the water in less time and increases the output of the solar still as compared with the traditional one. It is noticed that the efficiency and output of the solar still increased using a DC electric water heater.

\section{Recommendations}

In a solar water desalination unit, efficiency and output can be further increased from 10 to $20 \%$ by using reflectors that increase the amount of available radiation.

By using a double cover of glass on the top, the temperature difference in water between the basin and glass cover is increased.

Funding: This research received no external funding.

Data Availability Statement: Not applicable.

Conflicts of Interest: The authors declare no conflict of interest.

\section{References}

1. Attia, M.E.H.; Karthick, A.; Manokar, A.M.; Driss, Z.; Kabeel, A.E.; Sathyamurthy, R.; Sharifpur, M. Sustainable potable water production from conventional solar still during the winter season at Algerian dry areas: Energy and exergy analysis. J. Therm. Anal. Calorim. 2021, 145, 1215-1225. [CrossRef]

2. Hassan, H.; Ahmed, M.S.; Fathy, M.; Yousef, M.S. Impact of salty water medium and condenser on the performance of single acting solar still incorporated with parabolic trough collector. Desalination 2020, 480, 114324. [CrossRef]

3. Essa, F.; Abd Elaziz, M.; Elsheikh, A.H. An enhanced productivity prediction model of active solar still using artificial neural network and Harris Hawks optimizer. Appl. Therm. Eng. 2020, 170, 115020. [CrossRef]

4. Xu, Z.; Zhang, L.; Zhao, L.; Li, B.; Bhatia, B.; Wang, C.; Wilke, K.L.; Song, Y.; Labban, O.; Lienhard, J.H. Ultrahigh-efficiency desalination via a thermally-localized multistage solar still. Energy Environ. Sci. 2020, 13, 830-839. [CrossRef]

5. El-Gazar, E.; Zahra, W.; Hassan, H.; Rabia, S.I. Fractional modeling for enhancing the thermal performance of conventional solar still using hybrid nanofluid: Energy and exergy analysis. Desalination 2021, 503, 114847. [CrossRef]

6. Katekar, V.P.; Deshmukh, S.S. A review on research trends in solar still designs for domestic and industrial applications. J. Clean. Prod. 2020, 257, 120544. [CrossRef]

7. Mahboob, K.; Mushtaq, U.; Khan, A.; Awais, Q.; Zahid, T.; Ahmad, A.; Aslam, M.; Qaddus, A. Design and Modeling of Tubular Receiver of a Solar Tower Power Plant. Pak. J. Eng. Technol. 2021, 4, 201-206.

8. Mahboob, K.; Mahboob, A.; Husung, S. Virtual Reality (VR) for the Support of the Analysis and Operation of a Solar Thermal Tower Power Plant. In Proceedings of the ASME 2021 International Design Engineering Technical Conferences and Computers and Information in Engineering Conference, Online, Virtual, 17-19 August 2021.

9. Mahboob, K.; Khan, A.A.; Khan, M.A.; Sarwar, J.; Khan, T.A. Comparison of $\mathrm{Li}_{2} \mathrm{CO}_{3}-\mathrm{Na}_{2} \mathrm{CO}_{3}-\mathrm{K}_{2} \mathrm{CO}_{3}, \mathrm{KCl}_{-} \mathrm{MgCl}_{2}$ and NaNO $\mathrm{NaN}_{3}$ $\mathrm{KNO}_{3}$ as heat transfer fluid for different $\mathrm{sCO}_{2}$ and steam power cycles in CSP tower plant under different DNI conditions. Adv. Mech. Eng. 2021, 13. [CrossRef]

10. Essa, F.; Abdullah, A.; Omara, Z. Rotating discs solar still: New mechanism of desalination. J. Clean. Prod. 2020, $275,123200$. [CrossRef]

11. Abdullah, A.; Younes, M.; Omara, Z.; Essa, F. New design of trays solar still with enhanced evaporation methods-Comprehensive study. Sol. Energy 2020, 203, 164-174. [CrossRef]

12. Hassan, H.; Yousef, M.S.; Fathy, M.; Ahmed, M.S. Impact of condenser heat transfer on energy and exergy performance of active single slope solar still under hot climate conditions. Sol. Energy 2020, 204, 79-89. [CrossRef]

13. Abdullah, A.; Essa, F.; Bacha, H.B.; Omara, Z. Improving the trays solar still performance using reflectors and phase change material with nanoparticles. J. Energy Storage 2020, 31, 101744. [CrossRef] 